\title{
ROLE OF TAHIR POSHANJI ON BUILDING AN INDEPENDENT ISLAMIC STATE IN AFGHANISTAN (823 - 874 A.D.)
}

\author{
Enayatullah Dadman \\ Junior Teaching Assistant \\ Department of History Education Faculty \\ Kandahar University, Kandahar, Afghanistan \\ E-mail: dadmanenayat@gmail.com \\ Wafiullah Aminzai \\ Junior Teaching Assistant \\ History Department, Education Faculty \\ Kandahar, Afghanistan \\ E-mail: Wafiullah.aminzai2019@gmail.com \\ Mohibullah Dainsh \\ Junior Teaching Assistant \\ Department of History, Education Faculty \\ Sayed Jamaludin Afghani University \\ Kunar, Afghanistan \\ E-mail: mohibdanish30@gmail.com
}

\begin{abstract}
This review paper is descriptive in nature and as a time series it investigates role of Tahir Poshanji on building independent Islamic state in Afghanistan. The findings suggest that Tahir Poshanji like other Afghan leaders had a sense of freedom and people of Afghanistan have always made sacrifices for freedom. This caused failure of many great colonial states in their goals. The martyrdom of Abu Muslim caused movements and uprising in Afghanistan which put end to the power of Arab Muslims in Afghanistan. It was in progress until independent Islamic state was built by Tahirid. The war between Mamoon and his brother Ameen over Caliphate provided opportunity to Poshanji and his wish of changing capital of caliphate from Baghdad into Afghanistan. Tahir wanted Afghans to be ruled by people of the Islamic State. The conflicts between Afghans and Arabs were increasing every day. Poshanji started preparation for his map right after his appointment as governor in Afghanistan g to separate Afghanistan from Abbasid Empire. He dropped the caliph's name from KHUTBA (Islamic Sermon) and proclaimed an independent Islamic state in Afghanistan and raised flag of freedom. His relation with Baghdad Caliphate was only based on respect and not on domination.
\end{abstract}

Keywords: Conflict, Tahir Poshanji, Mamoon-ur- Rasheed, Independent State, Efforts. 


\section{INTRODUCTION}

Under the leadership of Tahir Poshanji, Afghans established the independent Islamic State for the first time. After Tahir Poshanji, rulers from his family played active roles in the spread of the holy religion of Islam and established Afghanistan's first Independent State in the history of new centuries. After Tahirid, the Safarid, Sassanid, Ghzanavid and Ghorid spread Islam throughout Afghanistan. After the death of Haroon-ur-Rasheed, his two sons, Amin and Mamoon had conflict over the caliphate. Soon after the death of Haroon-ur-Rasheed, Amin proclaimed his caliphate in Baghdad that his father had bequeathed to him. After he was stimulated by his minister Fazal Bin Rabi, he declared his little son as his crown prince. When Mamoon saw himself deprived of caliphate in the future, he started enmity with him. Amin wanted Mamoon to obey him as other local rulers of the Islamic Empire, but Mamoon disobeyed him and proclaimed himself as the caliph of Islam in Marwa. Consequently, Tahir took immense benefit of their conflict and started considering the establishment of Tahirid sequence. He managed to strengthen his influence in the Durbar of Mamoon and finally, he dropped his name from KHUTBA (Islamic Sermon) and proclaimed himself as an independent King.

\section{FINDINGS AND DISCUSSION}

The findings of this review paper show the comparatively analyzing Tahir Poshanji's government system to all previous contemporary governmental systems. Besides that, this paper shows how his bravery and honesty leaded him to change Caliphate and established an independent contemporary Islamic state in Afghanistan. How he ruled and why he changed Caliphate in modern Islamic state in Afghanistan are mean findings that have been discussed in this paper as follow.

\section{Tahirid State}

The people of Afghanistan have always made sacrifices for freedom which have caused the failure of many great colonial states in their goals. After the spread of Islam in Afghanistan and under the guidance of Abu Muslim Khorasani, the people of Afghanistan had a considerable role in the downfall of Amavid and empowerment of Abbasid during their conflicts. However, the caliph of the Abbasid, Abu Jafar Mansoor martyred Abu Muslim Khorasani very cruelly and violently, ignoring his service to the caliphate and he did not value the sacrifices made by Afghans. After the death of Haroon-ur-Rasheed when Amin proclaimed his caliphate in Baghdad and declared his little son as his crown prince, Mamoon-ur-Rasheed disobeyed him and proclaimed himself as the caliph in Marwa. Amin sent his soldiers against them, Mamoon also sent his army to fight against them. Tahir Poshanji managed to defeat Amin's Soldiers. Mamoon took the power, but when he changed the capital of caliphate from Afghanistan to Baghdad, he appointed Tahir as the governor of Khorasan. However, Tahir Poshanji like other Afghan Leaders had a sense of freedom in his mind. After two years, he proclaimed an independent Islamic state in Afghanistan and dropped Mamoon's name from KHUTBA (Islamic Sermon). Therefore, Tahir became an unbearable person for the caliph of Baghdad, Mamoon-ur-Raheed. With the help of his employees who were working with Tahir, he poisoned Tahir and martyred him. Tahir had founded an Independent State during one day. After that his son, Talha took the power and Mamoon recognized his sovereignty officially because he was compelled. Thus, the way for Sovereign Islamic State in the future was paved (Niazai, 1397). 


\section{Building Khorasani State in Afghanistan}

Tahir Poshanji son of Hussain Poshanji, the founder of Tahirid State, came to Afghanistan from Baghdad in 820 AD. In $822 \mathrm{AD}$, he established a sovereign Islamic State in Afghanistan and removed the name of Abbasid Claiph from KHUTBA (Islamic Sermon). He made a center in the Converted Muslims provinces of Afghanistan. After Tahir Poshanji, his brother Abdullah, and after Abdullah, Second Talha and the last king of this family Mohammad the son of Second Tahir took the throne consecutively. The last king unlike his ancestors was an irresponsible and luxurious person who paved the way for the collapse Tahiri's. He was imprisoned by Yaqub Lais Safari and thus the ruling period of Tahirid finished. The ruling period of Tahirid is considered to be a period of literature and people trusted them.

\section{Social and Cultural Condition of Afghanistan (from $9^{\text {th }}-13^{\text {th }}$ Century)}

During the (9-13 A.D. Centuries), social affairs faced various problems and improvements and during the mid-centuries, they almost reached the perfect and final stage. In this period, agriculture and irrigation system improved. Art and skills were at their peak. A number of literary works were done and tall buildings were built during the mentioned period. Afghanistan's large cities such as, Kabul, Herat, Balkh, Marv and Nesahpore were large business centers of Middle Asia. Only Balkh had a population of 200,000 people. Silky way which crossed the regions of Ghaznavid State, had always great caravans. These caravans transported the products to Afghanistan, Iran, China, India, Turkistan, Iraq, and Syria. The products included cloth, perfume, animals, medicines, metal products, weapons, precious stones, copper pots, paper, skin, leather, rice and ghee. In their daily life, people used wind mill, water mill, water wheel. barely, wheat, rice, cotton, grapes, agricultural products, vinegar and alcoholic drinks were also produced. In addition to agriculture, knitting rugs, cloth production, metal work, weapon production, making soaps, pots industry and painting were very common. Music had developed a lot as well. In large gatherings, singers sang with drums. States had disciplined civil and military structures. Religious subjects were taught in mosques. Many scholars and poets lived in this period (Ghubar, 1393).

\section{The Establishment of Tahirid State}

After the start and strength of anti-amavid movement by Abu Muslim Khorasani in Khorasan, Afghans were able to help Abbasid to seize power. These events brought a great change in the history of Islam. The martyrdom of Abu Muslim caused movements and uprising in Afghanistan which put an end to the power of Arab Muslims in Afghanistan. The said movement were in progress until an independent Islamic state was built by Tahirid in the country. These movements started earlier than Tahirid Rule in Sistan and Herat, but they became stronger during the conflict between Amin and Mamoon over caliphate after the death of Haroon-ur-Rasheed and it paved the way for an Islamic State of Khorasan under the leadership of Tahir Poshanji (Naeemi, 1391). Tahir son of Hussain was the founder of this ruling period. He was born in Poshanj (now called Zandahjan), Herat in a strong family. His grandfather was ruler of Poshanj during the rule of Abbasid. After that, his son Hussain was appointed as the ruler of Poshanj. Hussain's son, Tahir was a brave, independent and freedom loving personality. In fact, he was the main person who established the first Independent Islamic State (Bahar \& Sayed, 1388).

\section{Tahir Poshanji's Rule}

Tahirid laid the foundation of an Islamic State in Afghanistan. The founder of Tahirid family was Tahir Poshanji. Therefore this family is known as Tahirid. Tahir Poshanji, who was entitled "Zul- 
YAmin" by Mamoon, was born in 158 Hijri. He got education from his father. Tahir was son of Hussain and grandson of Mas'ab. His father was the governor of Poshanj during Mamoon-urRasheed rule. He died in 158 Hijri (Hashemi, 1354). Poshanj is located in the west of Herat City and it was the capital of Ghorid. In the south of Harirod River, there was a small town called Zandahjan which was located between Poshanj and Herat. This city is near Herat City and is in a distance of two FARSAKH from Herat City and nearby mountains. Poshanj Town was very beautiful, surrounded by green trees. It had strong fortifications. They city also had walls and craters around it. The Poshanj town was a well-built town till 178 Hijri. Behqi has mentioned its name as Foshanj, Poshanj or Poshang. The shrines of great scholars of Muslim World, Sheikh Abul Laith Poshanji and Sheikh Abul Hussain Poshanji still exist there. Both of them were famous personalities of the town (Naeemi, 1391). In his book "Historical Geography of Islamic Territories", Lustrunj has written about Poshanj: (It is one day away and this important town of Poshang, Foshang or Poshanj is located in Herat. It is almost the place which is now the city of Ghorid, located in the the south of Harirod River). In his book "Geographical Notes", Alama Academician Abdushakoor Rashad has said about Poshanj: "Most People consider current Zendahjan to be the ancient Foshanj. Zendahjan is located in the west of Herat almost 40 Kilo Meters away and if you go 26 Kilo meter further away from Zendahjan, you will arrive in Ghorid. Poshanj son of Hateeb Sadrudeen Rabi who was in the durbar of Kort Kings, attributed Poshnaj town to Hoshang." (Rashad, 1389 ).

According to Astakhari, "Poshanj Castle is a very strong castle surrounded by moats and has two gates) which were named Its eastern gate is called Ali. First Its western gate opens toward Neshapore and the second Its southern gate opens toward Qahqistan. Tahir Poshanji was a resident of this town and the following villages were in his territories before the Lame Timor: Ard, Khadez, Sadia, Arsho, Sangwan, Auah, Qourman, Ghanchad, Turkabad, Shakeban, Shadah, Muezak, Ouj, Kosan, Roshnan, Badah, Feshan, Astonan, and Rozan were part of this town (Rashad, 1389). The reputation of Tahir Poshanji increased when Haroon-ur-Rasheed's sons Amin and Mamoon had a conflict over caliphate. Before his death in 193 Hijri, Haroon-ur-Rasheed divided his great Islamic Empire by giving equal share to both of his sons, Amin who was the son of Zubaida daughter of Abu Jafar Mansoor and Mamoon who was the son of Marjeela daughter of Ustad Sis Sistani. The control of western parts of the empire was submitted to Amin-ur-Rasheed who was the grandson of Abu Jafar and belonged to the Abbasid. The eastern parts of the empire such as Persia, Kerman, Mazendran and Khorasan was submitted to Mamoon-ur-Rasheed whose mother was from Afghanistan. After the death of Haroon-ur-Rasheed, Amin got the chance and proclaimed himself as the caliph. Due to the stimulation by his minister Fazal Bin Rabi, he declared his little son Musa Bin Amin as his crown prince. When Mamoon saw himself deprived of caliphate in the future, he started enmity with him. Amin wanted Mamoon to obey him as other local rulers of the Islamic Empire, but Mamoon disobeyed him and proclaimed himself as the caliph of Islam in Marwa. In 196 Hijri, he made coins having his name, declared his sovereignty and showed his opposition with Baghdad (Niazai, 1397).

Amin-ur-Rasheed issued an order to remove Mamoon-ur-Rasheed from the government of Khorasan and sent troops for arresting Mamoon under the leadership of Ali Bin Musa. To fight the troops of Amin, Mamoon also sent soldiers under the leadership of Tahir Poshanji son of Hussain. Both armies had a clash in the (Rie) area. In this battle, 60000 soldier - army of Baghdad was defeated and Ali Bin Musa including a number of commanders were killed. Tahir was entitled "Zul- Yamin" by Mamoon. Tahir moved forward toward Baghdad and defeated other forces in the area of Hamdan sent by Baghdad. He continued moving forward toward Baghdad and besieged 
Baghdad City. The Besiege lasted a year and half. In this period Amin was killed by Tahir. In 198 Hijri, Baghdad was conquered by Tahir Poshanji which paved the way for the caliphate of Mamoon. Mamoon controlled all the areas of the caliphate from Marwa and appointed Tahir as the governor of Syria and Bain-un-Nahrain (Iraq). Tahir Poshangji wished to change the capital of caliphate from Baghdad into Afghanistan so all the areas of caliphate could be governed from Afghanistan. Tahir wanted Afghans to be ruling people of the Islamic State. Similarly, Mamoon selected Marwa as the capital of his caliphate and chose green flag instead of Abbasid Flag. However this plan could not be implemented till the end and could not last longer because some Arabs started revolting against him and appointed Mamoon's paternal uncle as their Caliph (Hashemi, 1354).

Appointment of Ibrahim as the caliph, death of Mamoon's son-in-law Ali Raza and the muder of his minister Fazal Bin Sohail and a number of other problems made the caliph to change his policies. He transferred the capital from Afghanistan back into Baghdad. After that, Tahir Poshanji strongly believed that his wish "transfer of capital to Afghanistan" cannot be achieved. He starting working to separate Afghanistan from The Abbasid Empire in order to make an independent Islamic state in Afghanistan. As the results and of his efforts and insistence, the caliph appointed him as the governor of Afghanistan. Mamoon knew that Tahir wanted to separate Afghanistan from the Abbasid Empire. The caliph could no longer tolerate the nearness of Afghans with the Arabs and the presence of Tahir Poshanji in Damascus because his problems were increasing day by day due to his presence. Also, the conflicts between Afghans and Arabs were increasing day by day. On the other hand, Tahir Poshanji started preparation for his map right after his appointment as governor in Afghanistan. On Jamad-ul-Akher, 24, 207 hijri on Friday, he dropped the caliph's name from KHUTBA (Islamic Sermon) and proclaimed an independent Islamic state in Afghanistan. He raised Afghanistan flag of freedom in the mountains. After that, the sequence of building independent Islamic States in Afghanistan started. Their relation with Baghdad Caliphate was only based on respect and not on domination. The kings of the Islamic States of Afghanistan were independent in all their affairs, but had a respect for Abbasid Rulers for maintaining spiritually friendly relationship with them. During his rule, there were Non-Islamic states in other parts of Afghanistan such as Kabul, Gandahara, Bluchistan, and so on (Hashemi, 1354).

Tahir could not live longer. He died on the night of independence proclamation. Many believed he was poisoned by the Arabs working with him on the order of Mamoon. Famous historian, Bartold has stated about his assassination, "Before taking control of Poshanj, Tahir Poshanji, the grandson of Mas'ab was the commander of Mamoom's army against the soldiers of Amin. After he conquered Baghdad, he was appointed as the governor of Iraq by Mamoon and in the meantime he was given financial responsibilities of Baghdad. It was done so Mamoon could frighten the friend and Companion of Tahir Poshanji, Ahmad Bin Abu Talib from the attack of the governor of Khorasan, Ghussan Bin Ibad. In the series of such conspiracies, the caliph appointed Tahir as the governor of Khorasan and Tahir proclaimed his independence from Baghdad Empire. Soon after the proclamation, he died who was probably poisoned on the order of the caliph." (Bartold, 1344).

Relying on historical evidences, Tahir Poshanji was poisoned by Mamoon. When he could kill his own brother for his rule, killing Tahir was much easier for him. After the caliph signed his appointment as the governor of Khorasan, he also appointed a close and trust-worthy person Kalsum Bin Sabit as the director of Khorasan Post office in order to inform the caliph of his acts. Also, he employed Khalid's father Ahamd who was the minister of Mamoon for giving 
information about Tahir to the caliph. He sent one of his close and trust-worthy people to Tahir apparently to serve him and secretly he was given the job to revolt and kill him if he proclaimed independence. When he dropped the caliph's name from KHUTBA (Islamic Sermon) and returned home after the proclamation of the independence of Khorasan, he felt weak and sick and it was thought the he had been poisoned. Tahir Poshanji passed away on the same night of proclamation day. The director of Khorasan post office and the agent of the caliph sent the written messages of proclamation of independence of Khorasan and the death of Tahir to the caliph consecutively (Naeemi, 1391).

\section{CONCLUSION}

The State of Tahirid was founded by Tahir Poshanji. He was living his life in the best cultural development period of Islam. There are several reasons for success in establishing a state of enlightenment and independence in Afghanistan. He took Mawra-un-Naher under his control. The rulers of Tahirid Family were highly educated. Tahir Poshanji was also a writer and poet of Arabic language. This ruling period was appropriate for construction and cultural activities. Rules for irrigation and getting advantages from water were made. His efforts for the spread of Islamic Education were highly remarkable. Tahir Poshanji very bravely sacrificed his life for the sake of building and stabilizing an independent Islamic state. Therefore, his efforts caused the latest rulers of Tahirid State to run their ruling affairs and serve the people of Afghanistan under the shade of independence and freedom in their territories. Although we have mentioned many times that Tahir Poshanji worked tirelessly in order to create his independent state, the last ruler of this family, Mohammad unlike his ancestors chose a different way and was engaged in debauching acts. He was unaware of the affairs of the government which caused the downfall of the Independent Islamic State founded by Tahir Poshanji. Tahir Poshanji, who was a bold and brave personality, never allowed anyone to interfere in governmental affairs. However, during Mohammad's rule due to his pleasure seeking acts, establishment and strength of Ayaran Movement, control of power by Mohammad Yaqub Lais, victory of Yaqub Lais over Mohammad, imprisonment of Mohammad by Yaqub Lais and Baghdad Empire's agreement were all the factors which led the Independent Islamic state and the power efforts to downfall that Tahir Poshanji had made for establishing an independent state.

\section{REFERENCES}

Bahar, K., \& Sayed, M. K. (1388). Mid-century History of Afghanistan. Translated by: Zakukhel, Mohammad Firdous. Kabul: Reprohindia.

Bartold. (1344). Political and Social History of Middle Asia in $12^{\text {th }}$ Century. Translated by: Ali Mohammad Zahma, Kabul. Education Press.

Ghubar, M. G. M.. (1393). Afghanistan in the perspectives of History (First and Second Part). Translated by: Dodial Mohammad Basheer. Kabul: Maiwand Publishing Organization.

Hashemi, S. (1354). History of Afghanistan in Islamic Period from the Establishment of National Islamic Government to the time of His Majesty, Ahmad Shah Abdali. Kabul: Kabul University

Naeemi, A. A. (1391). History of Afghanistan before Islam till Mohammadzis. Second Edition. Translated by: Irshad, Orangzeb. Kabul. Maiwand Publishing Organization. 
Naizai, M. (1397). Mid-century History of Afghanistan and Establishment of Sovereign States. Jalalabad: Hashemi Publishing Organization.

Rashad, A. (1389). Geographical Notes. (First and Second Part). Kandahar: Alama Rashad Academy.

\section{Copyrights}

Copyright for this article is retained by the author(s), with first publication rights granted to the journal. This is an open-access article distributed under the terms and conditions of the Creative Commons Attribution license (http://creativecommons.org/licenses/by/4.0) 